Volume 1 Issue 2, September 2017: pp. 252-277. Copyright (C) 2017 HOLREV. Faculty of Law, Halu Oleo University, Kendari, Southeast Sulawesi, Indonesia. ISSN: 2548-1762 | e-ISSN: 2548-1754. Open Access at: http://ojs.uho.ac.id/index.php/holrev/

\title{
Standar Pelayanan Medis Nasional sebagai Bentuk Pembatasan Otonomi Profesi Medis
}

\author{
National Medical Service Standard as Autonomy Limitation of \\ Medic Profession
}

\author{
Astutik \\ Fakultas Hukum Universitas Airlangga \\ Jl. Dharmawangsa Dalam Selatan Surabaya \\ E-mail:astutik@fh.unair.ac.id
}

\begin{abstract}
Principally relationships between Doctor and Patient have a contractual relationship as a strong effort in finding out the best solution for healing the patients that are well-known "Therapeutic Transaction". In order to keep-well relationship between Doctor and Patient, then that group must be liable for rights and obligation. Nevertheless, it excessively happened to patient loss due to disregard the rules that promulgated by Medics, one of them is medical service standard. The background of this research is to analyze the basis of national medical services and whether the form of national medical services was able to prevent dereliction of medic that inflicted the Patients. Consideration has declared standard of national medic service which fulfilled the rights of social health as well as increased the level of Indonesian publichealth. The rights of health have guaranteed on Constitution 1945, Laws 29 the Year 2004 Doctor Profession, Laws 36 the Year 2009 Health and other related ordinances including accommodated International Convention. A doctor, on one hand, has a duty to serve for the medical facility; an event he/she has autonomy profession, on the other hand has an independent profession that ought to be measured up by several rules either internal such code of conduct or profession standard including general rule services. Medical standard service is a binding rule for the professional groups in the field of health that are to straighten up health services and prevent dereliction on Medic Member Staff in handling medics.
\end{abstract}

Keyword: Medical services standard, autonomy, medical services, medical profession.

Abstrak: Pada dasarnya hubungan dokter-pasien adalah hubungan kontraktual sebagai upaya untuk mencari solusi terbaik bagi kesembuhan pasien yang dikenal dengan "Transaksi Terapeutik". Agar hubungan antara dokter dan pasien berjalan dengan baik, maka para pihak dibebani dengan hak dan kewajiban yang harus dilaksanakan. Namun demikian, tidak jarang atau sering terjadi adanya kerugian yang diderita oleh pasien akibat diabaikannya aturan-aturan yang telah ditetapkan 
di bidang medis, salah satunya adalah tidak dipenuhinya standar pelayanan medis. Dari latar belakang tersebut tulisan ini akan menganalisis dasar pertimbangan ditetapkannya standar pelayanan medis nasional dan apakah dibentuknya standar pelayanan medis nasional dapat mencegah terjadinya kelalaian medis yang merugikan pasien. Dasar pertimbangan ditetapkannya standar pelayanan medis nasional adalah untuk memenuhi hak atas kesehatan masyarakat dan meningkatkan derajat kesehatan yang setinggi-tingginya bagi masyarakat Indonesia. Hak atas kesehatan ini telah dijamin oleh UUD RI 1945, UU No. 29 Tahun 2004 tentang Profesi Kedokteran, UU No. 36 Tahun 2009 tentang Kesehatan dan peraturan lain yang terkait, termasuk telah diakomodir oleh berbagai konvensi Internasional. Seorang dokter yang bertugas memberikan pelayanan kesehatan, sekalipun di satu pihak mempunyai otonomi profesi, namun di lain pihak kemandirian tersebut perlu dibatasi dengan berbagai aturan mulai dari aturan intern berupa kode etik profesi, standar profesi dan standar pelayanan medis maupun aturan-aturan hukum. Standar pelayanan medis ini merupakan hukum yang mengikat para pihak yang berprofesi di bidang kesehatan, yaitu untuk mengatur pelayanan kesehatan dan mencegah terjadinya kelalaian stafmedis dalam melakukan tindakan medis.

Kata kunci: standar pelayanan medis, otonomi, pelayanan medis, profesi medis.

\section{PENDAHULUAN}

Pembangunan kesehatan merupakan bagian yang tak terpisahkan dari pembangunan nasional sehingga harus mempunyai acuan yang jelas tentang arah pembangunan kesehatan yang dapat dijadikan pedoman oleh seluruh komponen pelaku pembangunan. Untuk itu diperlukan dukungan sistem kesehatan nasional yang tangguh. Menurut Pasal 1 angka 2 Peraturan Presiden No. 72 Tahun 2012, Sistem Kesehatan Nasional, yang selanjutnya disingkat SKN adalah pengelolaan kesehatan yang diselenggarakan oleh semua komponen bangsa Indonesia secara terpadu dan saling mendukung guna menjamin tercapainya derajat kesehatan masyarakat yang setinggi-tingginya. Menurut Pasal 5 Perpres No. 72 Tahun 2012, SKN menjadi acuan dalam penyusunan dan pelaksanaan pembangunan kesehatan yang dimulai dari kegiatan perencanaan sampai dengan kegiatan monitoring dan evaluasi. Berdasarkan aturan tersebut, maka pelaksanaan pelayanan kesehatan harus dilakukan dengan menetapkan aturan yang dapat menjadi pedoman bagi sumber daya manusia di bidang kesehatan yang dalam penelitian ini adalah tenaga medis dalam melaksanakan pelayanan kesehatan.

Perlunya suatu standar dalam pelayanan medis bagi tenaga medis merupakan suatu kewajiban yang harus dipenuhi, dimana Undang-Undang No. 29 tahun 2004 tentang praktek kedokteran pasal 44 menyebutkan bahwa dokter atau dokter gigi dalam menyelenggarakan praktek kedokteran wajib mengikuti standar pelayanan kedokteran 
atau kedokteran gigi. Demikian juga dalam pasal 51 (UU yang sama) menyebutkan dokter atau dokter gigi dalam melaksanakan praktek kedokteran mempunyai kewajiban untuk memberikan pelayanan medis sesuai dengan standar profesi dan standar prosedur operasional serta kebutuhan medis pasien. Kewajiban untuk melaksanakan standar pelayanan medis juga diatur dalam Pasal 24 Undang-Undang No. 36 Tahun 2009 tentang kesehatan sebagai berikut:

(1) Tenaga kesehatan sebagaimana dimaksud dalam Pasal 23 harus memenuhi ketentuan kode etik, standar profesi, hak pengguna pelayanan kesehatan, standar pelayanan, dan standar prosedur operasional.

(2) Ketentuan mengenai kode etik dan standar profesi sebagaimana dimaksud pada ayat (1) diatur oleh organisasi profesi.

(3) Ketentuan mengenai hak pengguna pelayanan kesehatan, standar pelayanan, dan standar prosedur operasional sebagaimana dimaksud pada ayat (1) diatur dengan Peraturan Menteri.

Adanya UU N0. 29 tahun 2004 belum cukup menjadi jaminan terhindarnya kesalahan penanganan medis pada pasien. Beberapa temuan menginformasikan bahwa kesalahan penanganan medis masih sering terjadi. Kasus-kasus yang mencuat, seperti kesalahan pemberian obat, kesalahan diagnosis hingga kesalahan tindakan medis, menjadi peringatan agar kasus yang sama tidak terulang lagi. Rumah sakit, seharusnya memiliki standar pelayanan medis yang menjadi acuan dalam memberikan layanan medis kepada pasien. Sehingga, kebutuhan dasar masyarakat akan pelayanan kesehatan yang berkualitas dan patient safety dapat terpenuhi. Selain itu, standar pelayanan medis akan menjadi tolok ukur mutu pelayanan medis suatu rumah sakit dan menghindarkan rumah sakit dari kemungkinan tuntutan hukum jika terjadi medical error.

Standar pelayanan medis yang berlaku nasional di samping untuk membatasi otonomi profesi dokter juga untuk melindungi masyarakat secara keseluruhan. Kenyataan yang terjadi dalam praktek, banyak perbedaan dalam penanganan penderita pada saat pemeriksaan, maupun perbedaan mengenai sarana atau peralatan yang digunakan, sehingga semua ini bisa menyebabkan terjadi penyimpangan yang merugikan masyarakat. Dalam rangka menunjang kemandirian dan pelaksanaan profesi kedokteran dalam pelayanan kesehatan, Pemerintah menetapkan berlakunya standar pelayanan medis di rumah sakit dan standar pelayanan rumah sakit. Standar pelayanan medis tersebut merupakan tonggak utama dalam upaya peningkatan mutu pelayanan medis di Indonesia. 
Standar pelayanan medis ini merupakan hukum yang mengikat para pihak yang berprofesi di bidang kesehatan, yaitu untuk mengatur pelayanan kesehatan dan mencegah terjadinya kelalaian staf medis dalam melakukan tindakan medis. Dalam kaitannya dengan profesi medis, diperlukan standar pelayanan medis yang mencakup standar ketenangan, standar prosedur, standar sarana dan hasil yang diharapkan. Selain itu standar pelayanan medis tidak saja untuk mengukur mutu pelayanan, tetapi berfungsi juga untuk kepentingan pembuktian di pengadilan.

Mengingat begitu pentingnya standar pelayanan medis tersebut bagi profesi medis dalam melaksanakan pelayanan medis, maka penelitian ini akan mengkaji perlunya dibentuk standar pelayanan medis nasional dan sejauh mana standar pelayanan medis ini dapat menghindarkan dokter dari perbuatan yang menyimpang yang mengakibatkan kerugian bagi pasien.

\section{ANALISIS DAN PEMBAHASAN}

\section{Dasar Pertimbangan Dibentuknya Peraturan tentang Standar Pelayanan Medis} Nasional

Universal Declaration of Human Right (UDHR)/Deklarasi Universal Hak-Hak Asasi Manusia

Instrumen Internasional adalah perjanjian, dalam bentuk dan nama tertentu, yang diatur dalam hukum internasional yang dibuat secara tertulis serta menimbulkan kewajiban di bidang hukum publik. Prosedur perlindungan hak asasi manusia yang lahir dari berbagai perjanjian, hanya berlaku bagi negara-negara yang menjadi pihak pada perjanjian internasional tersebut. Sejalan dengan mandat piagam PBB, pada tahun 1948 PBB telah menerima Deklarasi Universal HAM yang meliputi pembukaan dan 30 pasal yang mengatur mengenai hak asasi manusia dan kebebasan dasar bagi seluruh perempuan dan pria di dunia tanpa adanya perbedaan. Dalam rangka penegakannya, perlu diberikan kekuatan hukum mengikat, prinsip-prinsip dalam Deklarasi Universal, dibakukan dalam dua kovenan utama PBB, yaitu Kovenan Internasional mengenai hak-hak sipil dan Politik (International Covenan on Civil and Political Rights) dan kovenan Internasional mengenai Hak-hak Ekonomi, Sosial, dan Budaya (International Covenant on Economic Social and Cultural Rights). 
Dasar Hukum atas pemeliharaan kesehatan dapat ditemukan dalam pasal 25 Universal Declaration of Human Rights Tahun 1948 yang dirumuskan sebagai berikut:

Article 25

(1) Everyone has the right to a standard of living adequate for the health and wellbeing of himself and of his family, including food, clothcing, housing, and medical care and necessery social service, and the right to security in the event of unemployment, sikcness, disability, widowhood, old age or other lack of livelihood in circumtances beyond his control.

(2) Motherhood and childhood are entitled to special care and asistance, all children, whether born in or out of wedlock shall enjoy the same social protection.

Berdasarkan pasal 25 Deklarasi Hak asasi manusia tersebut, maka setiap orang mempunyai hak atas kesehatan, khususnya bagi wanita dan anak-anak berhak mendapatkan pemeliharaan kesehatan dan bantuan secara khusus, meskipun anak tersebut lahir dalam perkawinan atau di luar perkawinan. Hak atas kesehatan pada dasarnya bertumpu pada dua dasar yaitu " Hak atas perawatan pemeliharaan medis dan hak untuk menentukan nasib sendiri, " (the right to health care dan the right to self determination). ${ }^{1}$

Hak atas kesehatan adalah hak setiap individu atau hak pasien atas pemeliharaan perawatan kesehatan bertolak dari hubungan asasi antara dokter dan pasien. Hak untuk menentukan nasib sendiri atau rights to self determination atau zelfbeshickkingsrecht. Hak untuk menentukan nasib sendiri adalah hak atas keamanan pribadi yang menyangkut mengenai hidup, bagian tubuh, kesehatan, kehormatan serta hak atas kebebasan pribadi. ${ }^{2}$

Ditinjau dari segi yuridis sosiologis, hak menentukan nasib sendiri terkait dengan kedudukan manusia sebagai individu yang mempunyai hak untuk menentukan masa depan bagi dirinya. Oleh karena itu hak ini hanya dapat diimplementasikan apabila individu diberi kebebasan secara mandiri untuk dengan bebas dan atas tanggung jawab sendiri memutuskan apa yang menjadi tujuan hidupnya dan untuk memenuhi tujuan hidupnya. Dalam perkembangannya hak untuk menentukan nasib sendiri dapat diartikan dalam dua hal yaitu:

1. Hak untuk menentukan sejauh mungkin segala sesuatu yang berhubungan dengan tubuh dan rohani.

Hermien Hadiati Koeswadji, Hukum dan Masalah Medik, Surabaya: Airlangga University Press, 1984, h.28.

Blacks Law Dictionary 
2. Hak untuk merencanakan, membentuk dan mengembangkan sebagaimana yang dikehendaki.

Hak untuk menentukan nasib sendiri dalam perkembangannya ditekankan pada kemampuan untuk mengetahui dan membandingkan kenyataan-kenyataan yang ada sehingga mampu mengambil keputusan terbaik atas dirinya. Dengan demikian hak menentukan nasib sendiri sangat erat hubungannya dengan hak atas informasi. Dengan informasi tersebut, maka pasien akan dapat menentukan keputusan yang terbaik bagi dirinya/keluarganya. Hak untuk menentukan nasib sendiri dalam Universal Declaration of Human Rights tahun 1948 dapat ditemukan dalam rumusan pasal-pasal sebagai berikut:

Article 3: "Everyone has the right to life, liberty, and the security of person ",

Article 5: " No one shall be subjected to torture or to cruel, inhuman or degrading treatment or punishment",

Article 9: No one shall be subjected to arbitrary arrest, detention, or exile",

Article 12: No one shall be subjected to arbitrary interference with his privacy, family, home or corespondence, nor to attacks upon his honour and reputation. Everyone has the right to the protection of the law against such interference or attacks",

Article 18: "Everyone has the right to freedom of thought, conscience and religion, this rights includes freedom to change his religion or belief, and freedom either alone or in community with others and in public or private, to manifest his religion or belief in teaching, practice, worship and observance.

Pasal-pasal tersebut di atas memang tidak secara tegas menyebut hak untuk menentukan nasib sendiri, namun ketentuan tersebut di atas menjadi dasar pengaturan perundang-undangan nasional terkait hak atas kesehatan.

\section{The United Nations International Covenant on Civil and Political Rights (ICCPR)}

a. Article 1: "All people have the right of self determination, by virtue of the right they freely determine their political status and freely pursue their economic, social and cultural development";

b. Article 2: Every human being has the inherent right to life. This right shall be arbitrary deprived of his life";

c. Article 3: "No one shall be subjected to torture or to cruel, inhuman or degrading treatment or punishment. In particular, no one shall be subjected without his free consent to medical or scientific experimentation" 
d. Pasal 6 Ayat (1): Setiap orang mempunyai hak untuk hidup. Hak ini harus dilindungi oleh hukum, tidak seorangpun manusia yang secara gegabah boleh dirampas penghidupannya.

e. Pasal 7: Tidak seorangpun boleh dikenakan penganiayaan atau perlakuan lain yang kejam, tidak manusiawi atau hukuman yang merendahkan harkatnya, teristimewa tidak seorangpun tanpa persetujuannya sendiri yang diberikan secara bebas boleh dijadikan sasaran percobaan medis atau ilmiah. Gagasan adanya perlindungan terhadap hak atas kesehatan terkait hak untuk tidak dijadikan sasaran percobaan medis adalah terjadinya percobaan-percobaan medis yang dilakukan oleh NAZI Jerman pada Perang Dunia ke dua terhadap tawanan-tawanan perang tanpa meminta persetujuan dari para korban. Berdasarkan kenyataan tersebut, kemudian diadakan deklarasi di Helsinki yang kemudian melahirkan nurenburg Code, dimana diberikan aturan bahwa percobaan medis yang menggunakan manusia harus dilakukan dengan persetujuan setelah diberikan informasi yang benar terkait penelitian yang akan dilakukan. Hal ini juga sebagai bentuk implementasi dari hak untuk menentukan nasib sendiri (Right to self Ditermination).

\section{International Covenant on Economic, Social and Cultural Right (ICESCR)}

Pasal 12: Setiap orang mempunyai hak untuk menikmati standar tertinggi yang dicapai atas kesehatan fisik dan mental.

Langkah-langkah yang akan diambil oleh Negara Pihak pada kovenan ini guna mencapai perwujudan hak ini sepenuhnya, harus meliputi hal-hal yang diperlukan untuk mengupayakan:

a. Ketentuan-ketentuan untuk pengurangan tingkat kelahiran-mati dan kematian anak serta perkembangan anak yang sehat;

b. Perbaikan semua aspek kesehatan lingkungan dan industri;

c. Pencegahan, pengobatan dan pengendalian segala penyakit menular, endemik, penyakit lainnya yang berhubungan dengan pekerjaan;

d. Penciptaan kondisi-kondisi yang akan menjamin semua pelayanan dan perhatian medis dalam hal sakitnya seseorang.

Konvensi ini telah diwujudkan oleh pemerintah dengan membuat regulasi terkait pelayanan kesehatan baik dalam bentuk Undang-undang maupun peraturan pemerintah, demikian juga di tingkat kabupaten/kota telah dibentuk regulasi yang tujuannya adalah 
untuk meningkatkan derajat kesehatan yang setinggi-tingginya bagi seluruh rakyat Indonesia tidak terkecuali bagi mereka yang kurang mampu. Untuk menjamin kesehatan bagi warga yang kurang mampu pemerintah bekerja sama dengan badan pemberi jaminan kesehatan nasional.

\section{Hukum Nasional yang mendasari diaturnya standar pelayanan medis dalam pelayanan kesehatan}

Undang-Undang Dasar Negara Republik Indonesia 1945

Dalam menjalankan hak dan kebebasannya, setiap orang wajib tunduk kepada pembatasan yang ditetapkan dengan undang-undang dengan maksud semata-mata untuk menjamin pengakuan serta penghormatan atas hak kebebasan orang lain dan untuk memenuhi tuntutan yang adil sesuai dengan pertimbangan moral, nilai-nilai agama, keamanan, dan ketertiban umum dalam suatu masyarakat Indonesia. Dasar pertimbangan diaturnya Standar pelayanan medis sebagai landasan konstitusionalnya yaitu, yaitu Undang-Undang Dasar Negara Republik Indonesia Tahun 1945 di antaranya:

a. Pasal 28A "Setiap orang berhak untuk hidup serta berhak mempertahankan hidup dan kehidupannya”.

b. Pasal 28B ayat (2) "Setiap anak berhak atas kelangsungan hidup, tumbuh, dan berkembang serta berhak atas perlindungan dari kekerasan dan diskriminasi.",

c. Pasal 28C ayat (1) "Setiap orang berhak mengembangkan diri melalui pemenuhan kebutuhan dasarnya, berhak mendapat pendidikan dan memperoleh manfaat dari ilmu pengetahuan dan teknologi, seni dan budaya, demi meningkatkan kualitas hidupnya dan demi kesejahteraan umat manusia".

d. Pasal 28H ayat (1) "Setiap orang berhak hidup sejahtera lahir dan batin, bertempat tinggal, dan mendapatkan lingkungan hidup yang baik dan sehat serta berhak memperoleh pelayanan

e. kesehatan",

f. Pasal 28H ayat (3) "Setiap orang berhak atas jaminan sosial yang memungkinkan pengembangan dirinya secara utuh sebagai manusia yang bermartabat",

g. Pasal 34 ayat (2) "Negara mengembangkan sistem jaminan sosial bagi seluruh rakyat dan memberdayakan masyarakat yang lemah dan tidak mampu sesuai dengan martabat kemanusiaan", dan 
h. Pasal 34 ayat (3) "Negara bertanggung jawab atas penyediaan fasilitas pelayanan kesehatan dan fasilitas pelayanan umum yang layak".

Ketetapan Majelis Permusyawaratan Rakyat Republik Indonesia Nomor XVII/MPR/1998 tentang Hak Asasi Manusia

Manusia sebagai makhluk Tuhan Yang Maha Esa secara kodrati dianugerahi hak dasar yang disebut hak asasi, tanpa perbedaan antara satu dengan lainnya. Dengan hak asasi tersebut, manusia dapat mengembangkan diri pribadi, peranan, dan sumbangannya bagi kesejahteraan hidup manusia. Manusia baik sebagai pribadi, maupun warga negara, dalam mengembangkan diri, berperan dan memberikan sumbangan bagi kesejahteraan hidup manusia, ditentukan oleh pandangan hidup dan kepribadian bangsa.

Pemahaman hak asasi manusia bagi bangsa Indonesia:

a. Hak asasi merupakan hak dasar seluruh umat manusia tanpa ada perbedaan. Mengingat hak dasar merupakan anugerah dari Tuhan Yang Maha Esa, maka pengertian Hak Asasi Manusia adalah hak sebagai anugerah Tuhan Yang Maha Esa yang melekat pada diri manusia, bersifat kodrati, universal dan abadi, berkaitan dengan hakikat dan martabat manusia;

b. Setiap manusia diakui dan dihormati mempunyai hak asasi yang sama tanpa membedakan jenis kelamin, warna kulit, kebangsaan, agama, usia, pandangan politik, status sosial, dan bahasa serta status lain. Pengabaian atau perampasannya mengakibatkan hilangnya harkat dan martabat sebagai manusia, sehingga kurang dapat mengembangkan diri dan peranannya secara utuh;

c. Bangsa Indonesia menyadari bahwa hak asasi manusia bersifat historis dan dinamis yang pelaksanaannya berkembang dalam kehidupan bermasyarakat, berbangsa dan bernegara. ${ }^{3}$

\section{Undang-Undang No. 33 Tahun 1999 tentang Hak Asasi Manusia}

Menurut pasal 1angka (1), Hak Asasi Manusia adalah seperangkat hak yang melekat pada hakikat dan keberadaan manusia sebagai makhluk Tuhan Yang Maha Esa dan merupakan anugerah-Nya yang wajib dihormati, dijunjung tinggi dan dilindungi oleh negara, hukum

3 Hari Sasangka dan Adnan Sagita, Peraturan PerUndang-Undangan tentang Hak Asasi Manusia (Susunan Dalam Satu Naskah), Mandar Maju, 2010, h. 96. 
dan pemerintah, dan setiap orang demi kehormatan serta perlindungan harkat dan martabat manusia.

a. Pasal 4: Hak untuk hidup, hak untuk tidak disiksa, hak kebebasan pribadi, pikiran dan hati nurani, hak beragama, hak untuk tidak diperbudak, hak untuk diakui sebagai pribadi dan persamaan di hadapan hukum, dan hak untuk tidak dituntut atas dasar hukum yang berlaku surut adalah hak-hak manusia yang tidak dapat dikurangi dalam keadaan apa pun dan oleh siapa pun.

b. Pasal 9: Setiap orang berhak untuk hidup, mempertahankan hidup dan meningkatkan taraf kehidupannya.

Undang-undang kesehatan yang lama lebih menitikberatkan pada pengobatan (kuratif), menyebabkan pola pikir yang berkembang di masyarakat adalah bagaimana cara mengobati bila terkena penyakit. Hal itu tentu akan membutuhkan dana yang lebih besar bila dibandingkan dengan upaya pencegahan. Konsekuensinya, masyarakat akan selalu memandang persoalan pembiayaan kesehatan sebagai sesuatu yang bersifat konsumtif/pemborosan. Selain itu sudut pandang para pengambil kebijakan juga masih belum menganggap kesehatan sebagai suatu kebutuhan utama dan investasi berharga di dalam pembangunan. Untuk itu, dalam pandangan UU kesehatan yang baru, persoalan kesehatan telah dijadikan sebagai suatu faktor utama dan investasi berharga yang pelaksanaannya didasarkan pada sebuah paradigma baru yang biasa dikenal dengan paradigma sehat, yakni paradigma kesehatan yang mengutamakan upaya promotif dan preventif tanpa mengabaikan upaya kuratif dan rehabilitatif.

\section{Undang-Undang No. 29 Tahun 2004 tentang Praktek Profesi Kedokteran}

Peraturan yang dasar dibentuknya standar pelayanan medis adalah adanya kewajiban dokter atau dokter gigi untuk melaksanakan tindakan medis berdasar standar pelayanan medis, sebagaimana diatur dalam:

Pasal 44:

(1) Dokter atau dokter gigi dalam menyelenggarakan praktek kedokteran wajib mengikuti standar pelayanan kedokteran atau kedokteran gigi.

(2) Standar pelayanan sebagaimana dimaksud pada ayat (1) dibedakan menurut jenis dan strata sarana pelayanan kesehatan.

(3) Standar pelayanan untuk dokter atau dokter gigi sebagaimana dimaksud pada ayat (1) dan ayat (2) diatur dengan Peraturan Menteri. 
Untuk melaksanakan pasal 44 tersebut di atas, pemerintah telah mengeluarkan Permenkes No. 43 Tahun 2016 tentang Standar Pelayanan minimal bidang kesehatan, Peraturan Menteri kesehatan Republik Indonesia Nomor 71 Tahun 2013 tentang Pelayanan Kesehatan pada Jaminan Kesehatan Nasional dan Permenkes RI No. 129/Menkes/Sk/2008 tentang Standar Pelayanan Minimal Rumah Sakit.

Pasal 50:

Dokter atau dokter gigi dalam melaksanakan praktek kedokteran mempunyai hak:

a. memperoleh perlindungan hukum sepanjang melaksanakan tugas sesuai dengan standar profesi dan standar prosedur operasional;

b. memberikan pelayanan medis menurut standar profesi dan standar prosedur operasional;

Pasal 51:

Dokter atau dokter gigi dalam melaksanakan praktek kedokteran mempunyai kewajiban:

a. memberikan pelayanan medis sesuai dengan standar profesi dan standar prosedur operasional serta kebutuhan medis pasien;

Undang-Undang No. 36 Tahun 2009 tentang Kesehatan

Pasal 24:

(1) Tenaga kesehatan sebagaimana dimaksud dalam Pasal 23 harus memenuhi ketentuan kode etik, standar profesi, hak pengguna pelayanan kesehatan, standar pelayanan, dan standar prosedur operasional.

(2) Ketentuan mengenai kode etik dan standar profesi sebagaimana dimaksud pada ayat (1) diatur oleh organisasi profesi.

(3) Ketentuan mengenai hak pengguna pelayanan kesehatan, standar pelayanan, dan standar prosedur operasional sebagaimana dimaksud pada ayat (1) diatur dengan Peraturan Menteri.

Pasal 51:

(1) Upaya kesehatan diselenggarakan untuk mewujudkan derajat kesehatan yang setinggi-tingginya bagi individu atau masyarakat.

(2) Upaya kesehatan sebagaimana dimaksud pada ayat (1) didasarkan pada standar pelayanan minimal kesehatan. 
(3) Ketentuan lebih lanjut mengenai standar pelayanan minimal kesehatan sebagaimana dimaksud pada ayat (2) diatur dengan Peraturan Pemerintah.

\section{Undang-Undang No. 36 Tahun 2014 tentang Tenaga Kesehatan}

Menurut Pasal 1 angka 1 Tenaga Kesehatan adalah setiap orang yang mengabdikan diri dalam bidang kesehatan serta memiliki pengetahuan dan/atau keterampilan melalui pendidikan di bidang kesehatan yang untuk jenis tertentu memerlukan kewenangan untuk melakukan upaya kesehatan.

\section{Pasal 57}

Tenaga Kesehatan dalam menjalankan praktek berhak:

a. memperoleh pelindungan hukum sepanjang melaksanakan tugas sesuai dengan Standar Profesi, Standar Pelayanan Profesi, dan Standar Prosedur Operasional

Pasal 58

(1) Tenaga Kesehatan dalam menjalankan praktek wajib:

a. memberikan pelayanan kesehatan sesuai dengan Standar Profesi, Standar Pelayanan Profesi, Standar Prosedur Operasional, dan etika profesi serta kebutuhan kesehatan Penerima Pelayanan Kesehatan;

\section{Pasal 11}

(1) Tenaga Kesehatan dikelompokkan ke dalam:
a. tenaga medis;
b. tenaga psikologi klinis;
c. tenaga keperawatan;
d. tenaga kebidanan;
e. tenaga kefarmasian;
f. tenaga kesehatan masyarakat;
g. tenaga kesehatan lingkungan;
h. tenaga gizi;
i. tenaga keterapian fisik;
j. tenaga keteknisian medis;
k. tenaga teknik biomedika;
l. tenaga kesehatan tradisional; dan
m. tenaga kesehatan lain. 
(2) Jenis Tenaga Kesehatan yang termasuk dalam kelompok tenaga medis sebagaimana dimaksud pada ayat (1) huruf a terdiri atas dokter, dokter gigi, dokter spesialis, dan dokter gigi spesialis.

Berdasarkan pengelompokan yang diatur dalam pasal 11 ayat (2) di atas, maka dokter dan dokter gigi adalah tenaga medis yang merupakan bagian dari tenaga kesehatan yang diatur dalam UU tenaga kesehatan. Sebagai bagian dari tenaga kesehatan, maka dalam melaksanakan tindakan medis atau untuk mendapatkan perlindungan hukum, maka setiap tenaga kesehatan dalam melaksanakan tugas wajib memenuhi standar profesi, standar pelayanan profesi dan standar operasional. Dalam hal tenaga medis, maka selain UU tenaga kesehatan, sudah ada UU Profesi Kedokteran yang mengatur khusus bagi profesi dokter dan dokter gigi.

\section{Standar Pelayanan Medis dalam Pelayanan Kesehatan Sebagai Upaya Mencegah Kelalaian Medis yang Merugikan Pasien}

Pelayanan kesehatan (health care service) merupakan hak setiap orang yang dijamin dalam Undang-Undang Dasar 1945 untuk melakukan upaya peningkatan derajat kesehatan baik perseorangan, maupun kelompok atau masyarakat secara keseluruhan. ${ }^{4}$ Definisi Pelayanan kesehatan menurut Departemen Kesehatan Republik Indonesia Tahun 2009 (Depkes RI) yang tertuang dalam Undang-Undang Kesehatan tentang kesehatan ialah setiap upaya yang diselenggarakan sendiri atau secara bersama-sama dalam suatu organisasi untuk memelihara dan meningkatkan kesehatan, mencegah dan menyembuhkan penyakit serta memulihkan kesehatan, perorangan, keluarga, kelompok ataupun masyarakat.

Berdasarkan Pasal 52 ayat (1) UU Kesehatan, pelayanan kesehatan secara umum terdiri dari dua bentuk pelayanan kesehatan yaitu:

a. Pelayanan kesehatan perseorangan (UKP)

b. Pelayanan Kesehatan Masyarakat (UKM)

UKP adalah setiap kegiatan yang dilakukan oleh pemerintah, masyarakat dan swasta untuk memelihara dan meningkatkan kesehatan serta untuk mencegah dan

$4 \quad$ Veronika komalawati. Op, Cit. h. 77 
menyembuhkan penyakit serta memulihkan kesehatan perseorangan. UKP mencakup upaya promotif, preventif, kuratif dan rehabilitatif.

UKM adalah kegiatan yang dilakukan oleh pemerintah, masyarakat atau swasta untuk memelihara dan meningkatkan kesehatan masyarakat serta mencegah dan menanggulangi masalah kesehatan yang timbul di masyarakat. UKM mencakup: upaya kesehatan berupa promosi kesehatan, pemeliharaan kesehatan, pemberantasan penyakit menular, kesehatan jiwa, pengendalian penyakit tidak menular, penyehatan lingkungan dan penyediaan sanitasi dasar, perbaikan gizi masyarakat, pengamanan sediaan farmasi dan alat kesehatan, pengamanan penggunaan zat adiktif (bahan tambahan) makanan dan minuman, pengamanan napza dan penanggulangan bencana serta bantuan kemanusiaan lainnya.

Prinsip-prinsip dalam upaya kesehatan yaitu:

1. Berkesinambungan dan paripurna

2. Bermutu, aman dan sesuai kebutuhan

3. Adil dan merata

4. Non Diskriminatif

5. Terjangkau

6. Teknologi tepat guna

7. Bekerja dalam tim secara cepat dan tepat

\section{Dasar Hukum Pelayanan Kesehatan}

Kesehatan merupakan kebutuhan dasar setiap manusia dan merupakan modal setiap warga negara dan setiap bangsa dalam mencapai tujuannya dan mencapai kemakmuran. Seseorang tidak bisa memenuhi seluruh kebutuhan hidupnya jika dia berada dalam kondisi tidak sehat. Sehingga kesehatan merupakan modal setiap individu untuk meneruskan kehidupannya secara layak. Pemerintah mempunyai tanggung jawab untuk menjamin setiap warga negara memperoleh pelayanan kesehatan yang berkualitas sesuai dengan kebutuhan. Sebagai suatu kebutuhan dasar, setiap individu bertanggung jawab untuk memenuhi kebutuhan hidup dirinya dan orang- orang yang menjadi tanggung jawabnya, sehingga pada dasarnya pemenuhan kebutuhan masyarakat terhadap kesehatan adalah tanggung jawab setiap warganegara. Meskipun upaya untuk memenuhi kebutuhan bidang kesehatan melekat pada setiap warga negara, namun mengingat karakteristik barang/jasa kesehatan tidak dapat diusahakan/diproduksi sendiri secara 
langsung oleh masing-masing warga negara, melainkan harus ada pihak lain yang secara khusus memproduksi dan menyediakannya, maka penyediaan barang/jasa bidang kesehatan mutlak memerlukan keterlibatan pemerintah untuk:

Menjamin tersedianya barang/jasa kesehatan yang dapat diperoleh warga negara yang memerlukan sesuai dengan kebutuhannya; Menyediakan barang/jasa kesehatan bagi warga negara yang tidak mampu memenuhi kebutuhannya di bidang kesehatan. Mengingat kebutuhan warga negara terhadap barang/jasa kesehatan sangat vital dan dengan karakteristik barang/jasa kesehatan yang unik dan kompleks, maka peranan pemerintah di bidang kesehatan harus di standarisasi agar warga negara dapat memenuhi kebutuhannya di bidang kesehatan. Sejak era reformasi urusan pemerintahan secara bertahap diserahkan dari Pemerintah Pusat kepada Pemerintah Daerah (Pemda) dan hal ini sesuai dengan pasal 18 ayat (6) amandemen UUD 1945 yang menyatakan bahwa pemerintahan daerah menjalankan otonomi seluas- luasnya. Peraturan terakhir yang mengatur tentang pembagian urusan antara Pemerintah Pusat dan Pemerintah Daerah adalah UU Nomor 23 Tahun 2014 yang merupakan pengganti UU Nomor 32 Tahun 2004. Pada UU 23 Tahun 2014 tentang Pemerintahan Daerah, kesehatan adalah satu dari enam urusan concurrent (bersama) yang bersifat wajib dan terkait dengan pelayanan dasar. Enam urusan tersebut adalah:

1. Pendidikan

2. Kesehatan

3. Pekerjaan Umum dan Penataan Ruang

4. Perumahan Rakyat dan Kawasan Pemukiman

5. Ketenteraman dan ketertiban Umum serta Perlindungan Masyarakat

6. Sosial.

Karena kondisi kemampuan sumber daya Pemda di seluruh Indonesia tidak sama dalam melaksanakan keenam urusan tersebut, maka pelaksanaan urusan tersebut diatur dengan Standar Pelayanan Minimal (SPM) untuk memastikan ketersediaan layanan tersebut bagi seluruh warga negara. SPM sekurangnya mempunyai dua fungsi yaitu (i) memfasilitasi Pemda untuk melakukan pelayanan publik yang tepat bagi masyarakat dan (ii) sebagai instrumen bagi masyarakat dalam melakukan kontrol terhadap kinerja pemerintah di bidang pelayanan publik bidang kesehatan.

Standar Pelayanan Minimal adalah ketentuan mengenai jenis dan mutu pelayanan dasar yang merupakan urusan pemerintahan wajib yang berhak diperoleh setiap warga 
negara secara minimal. SPM dengan konsep baru ini mengalami perubahan yang cukup mendasar dari konsep SPM sebelumnya. Bila pada SPM yang lalu pencapaian target-target SPM lebih merupakan kinerja program kesehatan maka pada SPM ini pencapaian targettarget tersebut lebih diarahkan kepada kinerja Pemda. Pencapaian target SPM, bersamasama dengan program prioritas lain, menjadi indikator apakah kinerja Kepala Daerah dinilai baik atau tidak dan sebagaimana telah diatur dalam UU 23 Tahun 2014 maka ada konsekuensi tertentu atas tercapai/tidaknya indikator-indikator ini. SPM juga akan berfungsi sebagai instrumen untuk memperkuat pelaksanaan Performance Based Budgeting. UU 23 Tahun 2014 juga mengamanatkan pada Pemda untuk benar-benar memprioritaskan belanja daerah untuk mendanai urusan pemerintahan wajib yang terkait pelayanan dasar yang ditetapkan dengan SPM (pasal 298). Ke depannya nanti pengalokasian DAK ke daerah akan berdasar pada kemampuan daerah untuk pencapaian target-target SPM, daerah dengan kemampuan sumber daya yang kurang akan menjadi prioritas dalam pengalokasian DAK.

Hal-hal tersebut di atas membuat seluruh elemen akan bersatu padu berbenah untuk bersama-sama menuju pencapaian target-target SPM, termasuk di dalamnya adalah pemenuhan sumber daya manusia kesehatan terutama di level Puskesmas sesuai Permenkes Nomor 75 Tahun 2014 tentang Pusat Kesehatan Masyarakat. Puskesmas sebagai fasilitas pelayanan kesehatan tingkat pertama akan menjadi unit terdepan dalam upaya pencapaian target-target SPM. Implementasi SPM juga menjadi sangat strategis dalam kaitannya dengan pelaksanaan Jaminan Kesehatan Nasional (JKN), yang sampai saat ini masih bermasalah dengan adanya defisit anggaran. Implementasi SPM akan memperkuat sisi promotif-preventif sehingga diharapkan akan ber-impact pada penurunan jumlah kasus kuratif yang harus ditanggung oleh JKN.

Dalam Peraturan Menteri Dalam Negeri Republik Indonesia Nomor 18 Tahun 2016 Tentang Pedoman Penyusunan, Pengendalian dan Evaluasi Rencana Kerja Pemerintah Daerah Tahun 2017 berisi arah kebijakan pembangunan daerah yaitu untuk menjamin sinergisitas program pembangunan nasional dan daerah, dimana penyusunan RKPD Tahun 2017 berdasarkan arah kebijakan pembangunan daerah dengan memperhatikan prioritas dan sasaran pembangunan nasional. Arah kebijakan pembangunan daerah tersebut berpedoman pada Standar Pelayanan Minimal (SPM) sesuai dengan UndangUndang Nomor 23 Tahun 2014 tentang Pemerintahan Daerah bahwa terdapat 6 (enam) urusan pemerintahan wajib yang berkaitan dengan pelayanan dasar yang terdiri dari 
Pendidikan; Kesehatan; Pekerjaan Umum dan Penataan Ruang; Perumahan Rakyat dan Kawasan Permukiman; Ketenteraman, Ketertiban Umum dan Perlindungan Masyarakat; dan Sosial serta beberapa prioritas lainnya. Dalam rangka penerapan SPM Bidang Kesehatan diperlukan Petunjuk Teknis Pelaksanaan SPM yang menjelaskan langkah operasional pencapaian SPM Bidang Kesehatan di Kabupaten/Kota sebagai acuan bagi pemerintah daerah dengan memperhatikan pembiayaan.

Semakin meningkatnya kebutuhan masyarakat akan pelayanan kesehatan, maka semakin berkembang juga aturan dan peranan hukum dalam mendukung peningkatan pelayanan kesehatan, alasan ini menjadi faktor pendorong pemerintah dan institusi penyelenggara pelayanan kesehatan untuk menerapkan dasar dan peranan hukum dalam meningkatkan pelayanan kesehatan yang berorientasi terhadap perlindungan dan kepastian hukum pasien.

Dasar hukum pemberian pelayanan kesehatan secara umum diatur dalam Pasal 53 UU Kesehatan, yaitu:

a. Pelayanan kesehatan perseorangan ditujukan untuk menyembuhkan penyakit dan memulihkan kesehatan perseorangan dan keluarga.

b. Pelayanan kesehatan masyarakat ditujukan untuk memelihara dan meningkatkan kesehatan serta mencegah penyakit suatu kelompok dan masyarakat.

Kegiatan pelayanan kesehatan secara paripurna diatur dalam Pasal 52 ayat (2) UU Kesehatan sebagaimana dimaksud pada ayat (1), yaitu:

a. Pelayanan kesehatan promotif, suatu kegiatan dan/atau serangkaian kegiatan pelayanan kesehatan yang lebih mengutamakan kegiatan yang bersifat promosi kesehatan.

b. Pelayanan kesehatan preventif, suatu kegiatan pencegahan terhadap suatu masalah kesehatan/penyakit.

c. Pelayanan kesehatan kuratif, suatu kegiatan dan/atau serangkaian kegiatan pengobatan yang ditujukan untuk penyembuhan penyakit, pengurangan penderitaan akibat penyakit, pengendalian penyakit, pengendalian kecacatan agar kualitas penderita dapat terjaga seoptimal mungkin.

d. Pelayanan kesehatan rehabilitatif, kegiatan dan/atau serangkaian kegiatan untuk mengembalikan bekas penderita ke dalam masyarakat sehingga dapat 
berfungsi lagi sebagai anggota masyarakat yang berguna untuk dirinya dan masyarakat, semaksimal mungkin sesuai dengan kemampuannya.

Melalui ketentuan UU Kesehatan dan UU Rumah Sakit dalam hal ini pemerintah dan institusi penyelenggara pelayanan kesehatan yakni rumah sakit, memiliki tanggung jawab agar tujuan pembangunan di bidang kesehatan mencapai hasil yang optimal, yaitu melalui pemanfaatan tenaga kesehatan, sarana dan prasarana, baik dalam jumlah maupun mutunya, baik melalui mekanisme akreditasi maupun penyusunan standar, harus berorientasi pada ketentuan hukum yang melindungi pasien, sehingga memerlukan perangkat hukum kesehatan yang dinamis yang dapat memberikan kepastian dan perlindungan hukum untuk meningkatkan, mengarahkan, dan memberi dasar bagi pelayanan kesehatan. Undang-Undang No. 29 Tahun 2004 pasal 44 merumuskan bahwa Dokter atau dokter gigi dalam menyelenggarakan praktek kedokteran wajib mengikuti standar pelayanan kedokteran atau kedokteran gigi. Demikian juga dalam pasal 55 dirumuskan bahwa Dokter atau dokter gigi dalam melaksanakan praktek kedokteran mempunyai kewajiban memberikan pelayanan medis sesuai dengan standar profesi dan standar prosedur operasional serta kebutuhan medis pasien.

Untuk bisa melaksanakan kewajiban memberikan pelayanan yang terbaik bagi pasien, maka fasilitas kesehatan tempat pelayanan kesehatan dilakukan harus memiliki standar pelayanan medis yang harus ditaati oleh para pemberi pelayanan kesehatan khususnya dokter. Pemerintah sudah mengeluarkan beberapa peraturan terkait pedoman untuk melakukan pelayanan medis di Rumah sakit di antaranya: Permenkes No. 43 Tahun 2016 tentang Standar Pelayanan minimal bidang kesehatan, Peraturan Menteri kesehatan Republik Indonesia Nomor 71 Tahun 2013 tentang Pelayanan Kesehatan pada Jaminan Kesehatan Nasional dan Permenkes RI No. 129/Menkes/Sk/2008 tentang Standar Pelayanan Minimal Rumah Sakit. Aturan-aturan tersebut menjadi pedoman bagi Rumah sakit dan dokter untuk memberikan pelayanan minimal kepada pasien. Dari Permenkes tentang Standar Pelayanan minimal tersebut, Rumah Sakit dan Fasilitas pelayanan kesehatan yang lain harus membuat Standar Operasional Prosedur terhadap setiap kegiatan yang dilakukan tenaga kesehatan yang bekerja di fasilitas pelayanan kesehatan tersebut.

Fungsi standar pelayanan medis dan standar operasional prosedur, tidak hanya berguna sebagai pedoman dalam memberikan pelayanan kesehatan pada pasien, standarstandar tersebut juga berguna sebagai batasan terhadap otonomi profesi yang dimili oleh 
tenaga kesehatan yang bekerja di fasilitas pelayanan kesehatan khususnya di Rumah Sakit. Batasan ini perlu diberikan agar para tenaga kesehatan tidak melakukan penyimpangan dalam pemberian pelayanan kesehatan kepada pasien yang bisa mengakibatkan terjadinya kerugian pada pasien. Selain adanya standar-standar tersebut di atas, undangundang No. 36 tahun 2009 tentang kesehatan juga mengatur kewajiban Rumah sakit dalam memberikan pelayanan kesehatan terhadap pasien.

Dalam Pasal 54 UU Kesehatan diatur pemberian pelayanan kesehatan, yaitu:

a. Penyelenggaraan pelayanan kesehatan dilaksanakan secara bertanggung jawab, aman, bermutu, serta merata dan non diskriminatif.

b. Pemerintah dan pemerintah daerah bertanggung jawab atas penyelenggaraan pelayanan kesehatan sebagaimana dimaksud pada ayat (1).

c. Pengawasan terhadap penyelenggaraan pelayanan kesehatan sebagaimana dimaksud pada ayat (1) dilakukan oleh pemerintah, pemerintah daerah, dan masyarakat.

Pelayanan kesehatan itu sebenarnya juga merupakan perbuatan hukum, yang mengakibatkan timbulnya hubungan hukum antara pemberi pelayanan kesehatan dalam hal ini rumah sakit terhadap penerima pelayanan kesehatan, yang meliputi kegiatan atau aktivitas profesional di bidang pelayanan preventif dan kuratif untuk kepentingan pasien. Secara khusus dalam Pasal 29 ayat (1) huruf (b) UU Rumah Sakit, rumah sakit mempunyai kewajiban memberikan pelayanan kesehatan yang aman, bermutu, anti diskriminasi, dan efektif dengan mengutamakan kepentingan pasien sesuai dengan standar pelayanan rumah sakit.

Peraturan atau dasar hukum dalam setiap tindakan pelayanan kesehatan di rumah sakit wajib dilaksanakan sesuai dengan ketentuan Pasal 53 dan Pasal 54 UU Kesehatan sebagai dasar dan ketentuan umum dan ketentuan Pasal 29 ayat (1) 12

Dengan dipenuhinya standar profesi, standar pelayanan medis dan standar-standar yang lain, maka tenaga kesehatan akan mendapatkan perlindungan hukum dan pasien akan mendapatkan pelayanan kesehatan sesuai dengan ketentuan undang-undang yaitu mendapatkan pelayanan kesehatan yang bermutu. Pelayanan kesehatan yang bermutu merupakan salah satu tujuan dari upaya kesehatan yang diatur dalam peraturan presiden No. 72 Tahun 2012 tentang Sistem Kesehatan Nasional. 


\section{Hubungan Hukum dalam Pelayanan Kesehatan}

Hubungan hukum antara pasien dengan penyelenggara kesehatan dan pihak pelayanan kesehatan (dalam hal ini rumah sakit, dokter, perawat, bidan) dalam melakukan hubungan pelayanan kesehatan. Pertama adalah hubungan medis yang diatur oleh kaidah-kaidah medis, dan kedua adalah hubungan hukum yang diatur oleh kaidah-kaidah hukum baik yang tertulis maupun yang tidak tertulis. Hubungan hukum yang terjadi dalam pelayanan medis ialah berdasarkan perjanjian yang bertujuan untuk melakukan pelayanan dan pengobatan pasien demi kesembuhan pasien. ${ }^{5}$

Upaya pelayanan kesehatan di rumah sakit bertolak dari hubungan dasar dalam bentuk transaksi terapeutik. Transaksi terapeutik sebagai suatu transaksi mengikat antara pihak pemberi pelayanan dengan pasien sebagai penerima pelayanan dalam perikatan transaksi terapeutik tersebut. Untuk menilai sahnya perjanjian hubungan hukum dalam pelayanan kesehatan tersebut diatur dalam Pasal 1320 KUHPerdata, bahwa unsur-unsur syarat perjanjian dalam transaksi terapeutik meliputi:

a. Adanya sepakat dari mereka yang mengikatkan dirinya.

b. Adanya kecakapan antara pihak membuat perikatan.

c. Suatu hal tertentu yang diperbolehkan.

d. Karena suatu sebab yang halal.

Perjanjian yang dilakukan antara pasien dan pemberi pelayanan kesehatan berdasarkan Pasal 1320 KUHPerdata dijadikan tolok ukur berdasarkan syarat sah terjadinya perjanjian antara pasien dan pemberi pelayanan kesehatan berdasarkan perjanjian terapeutik yang melahirkan hak dan kewajiban bagi para pihak dalam melaksanakan upaya penyembuhan.

Secara umum dalam hubungan hukum antara penyelenggara pelayanan kesehatan dengan pasien ialah upaya penyembuhan bukan merupakan perikatan hasil (resultaasverbitenis), melainkan perikatan usaha (inspanningsverbintenis) secara maksimal dan berdasarkan prinsip kehati-hatian yang hasilnya belum pasti. Sebaliknya pasien juga harus memberikan informasi secara jelas, lengkap dan jujur kepada dokter terkait dengan penyakit yang dideritanya. Sehingga, tidak menyebabkan kesalahpahaman antara kedua belah pihak guna tercapainya tujuan pelayanan kesehatan yang lebih optimal.

5 Hermien Hadiati Koeswadji. Hukum Kedokteran, Bandung: PT. Citra Aditya Bakti, 1998, h. 101. 
Apabila pasien dan keluarganya menyetujui untuk menjalani pelayanan kesehatan di rumah sakit, maka rumah sakit bersedia untuk memberikan pelayanan kesehatan yang diperlukan pasien, maka hak dan kewajiban pasien dan rumah sakit timbul sejak pasien masuk ke rumah sakit dan sepakat untuk mendapatkan pelayanan kesehatan.

Pasien dengan segala kewajibannya yang telah ditentukan oleh rumah sakit berhak atas pelayanan kesehatan sesuai dengan indikasi penyakit pasien tersebut. Dalam perjanjian ini kewajiban rumah sakit adalah melakukan penyediaan fasilitas perawatan yakni sarana alat kesehatan, dokter, tenaga kesehatan dengan tujuan memberikan pelayanan kesehatan yang optimal kepada pasien.

Hak dan kewajiban pasien dan dokter atau tenaga kesehatan lain yang terlibat dalam pelayanan kesehatan harus dilakukan secara seimbang, hal ini untuk mencegah timbulnya tuntutan pasien akibat perbuatan dokter atau tenaga kesehatan yang merugikan pasien. Dokter sebagai anggota profesi yang mengabdikan ilmunya pada kepentingan umum, mempunyai kebebasan serta kemandirian yang berorientasi pada nilai-nilai kemanusiaan di bawah panji kode etik kedokter.an. Dalam UU profesi kedokteran maupun dalam UU kesehatan yang telah dikemukakan sebelumnya, bahwa dalam melaksanakan tugas pelayanan medis, dokter mempunyai kewajiban untuk mematuhi standar profesi, standar pelayanan medis dan standar operasional, jika ingin mendapatkan perlindungan hukum. Di samping melakukan kewajiban-kewajibannya, dokter juga harus menghormati pasien dalam melakukan tindakan medis. Dokter sebagai suatu profesi dalam melakukan tugasnya dilandasi oleh dua prinsip perilaku pokok yaitu berbuat demi kebaikan pasien (beneficence) dan tidak ada niat untuk menyakiti, mencederai, dan merugikan pasien (non malaficence). ${ }^{6}$ Seorang dokter yang bertugas memberikan pelayanan kesehatan, sekalipun di satu pihak mempunyai otonomi profesi, namun di lain pihak kemandirian tersebut perlu dibatasi dengan berbagai aturan mulai dari aturan intern berupa kode etik profesi, standar profesi dan standar pelayanan medis maupun aturan-aturan hukum.

Berdasarkan hasil penelitian yang telah dilakukan, saat ini belum ada standar pelayanan medis yang dibentuk oleh Pemerintah, tetapi Pemerintah telah mengeluarkan beberapa peraturan menteri kesehatan terkait standar pelayanan medis minimal bidang kesehatan dan standar pelayanan minimal di Rumah Sakit. Standar pelayanan medis

6 Bahder Johan Nasution, Op.Cit, h. 41. 
tersebut adalah tonggak utama dalam upaya peningkatan mutu pelayanan medis di Indonesia. Tujuan ditetapkannya standar pelayanan medis ini adalah untuk melindungi masyarakat dari praktek-praktek yang tidak sesuai dengan standar profesi. Di samping untuk melindungi masyarakat, tujuan dibuatnya standar pelayanan medis juga untuk memberikan perlindungan bagi profesi medis dari tuntutan-tuntutan yang tidak wajar. Selain itu juga dimaksudkan sebagai pedoman dalam pengawasan dan pembinaan, serta peningkatan mutu pelayanan kesehatan yang efektif dan efisien.

Standar pelayanan medis ini merupakan hukum yang mengikat para pihak yang berprofesi di bidang kesehatan, yaitu untuk mengatur pelayanan kesehatan dan mencegah terjadinya kelalaian staf medis dalam melakukan tindakan medis. Dalam kaitannya dengan profesi dokter diperlukan standar pelayanan medis yang mencakup: standar ketenangan, standar prosedur, standar sarana, dan standar hasil yang diharapkan. Selain itu standar pelayanan medis ini tidak saja mengukur pelayanan, tetapi juga berfungsi untuk kepentingan pembuktian di pengadilan apabila timbul sengketa. Standar pelayanan medis terdiri dari dua bagian yaitu:

1. Memuat standar penyakit dengan dua belas spesialisasi kasus-kasus penting.

2. Memuat tentang standar pelayanan penunjang dengan tiga spesialisasi yang masing-masingnya dirinci berdasarkan prosedur tindakan yang harus ditangani oleh spesialisasi yang bersangkutan. Bagian dari standar pelayanan medis yang pertama meliputi:
a. Bagian bedah
b. Bagian bedah ortopedi
c. Bagian jiwa
d. Bagian kardiologi
e. Bagian kulit dan kelamin
f. Bagian obstetri dan ginekologi
g. Bagian paru
h. Bagian penyakit dalam
i. Bagian penyakit anak
j. Bagian syaraf
k. Bagian mata
1. Bagian hidung, telinga dan tenggorokan.
Sedangkan bagian standar pelayanan medis kedua, meliputi: 

a. Bagian anestesi
b. Bagian patologi, anatomi, forensik, klinik
c. Bagian radiologi.

Sebagai suatu standar dalam pelayanan kesehatan di Rumah sakit, bagian-bagian di atas, baik mengenai standar penyakit dengan spesialisasinya maupun mengenai standar penunjang, dapat selalu berkembang sesuai dengan kebutuhan perkembangan ilmu pengetahuan dan kemajuan teknologi di bidang kesehatan.

Banyaknya bagian yang harus ada dalam pelayanan kesehatan, menjadi kendala untuk dibentuknya standar pelayanan medis nasional, karena setiap rumah sakit tidak sama dan tidak selalu mempunyai alat dan fasilitas yang sama. Oleh karena itu pemerintah hanya memberikan aturan tentang standar pelayanan minimal yang harus ada di rumah sakit, untuk selanjutnya rumah sakit dan fasilitas pelayanan kesehatan yang ada, harus menentukan sendiri standar operasional untuk masing-masing tindakan medis yang akan dilakukan. Sampai saat ini, beberapa Rumah sakit pada umumnya sudah mempunyai standar pelayanan minimal yang harus ada di rumah sakit, namun demikian standar ini belum bisa dijadikan alat untuk mencegah kelalaian yang dilakukan tenaga medis di rumah sakit dan tidak bisa dijadikan standar pokok, karena setiap rumah sakit mempunyai standar yang berbeda tergantung tipe rumah sakitnya. Namun demikian dengan adanya standar pelayanan medis di rumah sakit ini, setidak-tidaknya tenaga medis di rumah sakit harus mematuhi standar-standar yang telah ditetapkan sebagai kewajiban etik dan kewajiban hukum, jika ini dilanggar dan mengakibatkan kerugian pasien, maka tenaga medis tidak bisa menghindarkan diri dari tuntutan pasien. Dengan demikian standar pelayanan medis tidak hanya berfungsi untuk membatasi otonomi profesi tenaga medis, tapi juga dapat digunakan sebagai alat bukti jika terjadi tuntutan hukum.

\section{KESIMPULAN}

1. Dasar pertimbangan ditetapkannya standar pelayanan medis nasional adalah untuk memenuhi hak atas kesehatan masyarakat dan meningkatkan derajat kesehatan yang setinggi-tingginya bagi masyarakat Indonesia. Hak atas kesehatan ini telah dijamin oleh UUD RI 1945, UU No. 29 Tahun 2004 tentang Profesi Kedokteran, UU No. 36 Tahun 2009 tentang Kesehatan dan peraturan lain yang terkait, termasuk telah diakomodir oleh berbagai konvensi Internasional. 
2. Seorang dokter yang bertugas memberikan pelayanan kesehatan, sekalipun di satu pihak mempunyai otonomi profesi, namun di lain pihak kemandirian tersebut perlu dibatasi dengan berbagai aturan mulai dari aturan intern berupa kode etik profesi, standar profesi dan standar pelayanan medis maupun aturan-aturan hukum. Standar pelayanan medis ini merupakan hukum yang mengikat para pihak yang berprofesi di bidang kesehatan, yaitu untuk mengatur pelayanan kesehatan dan mencegah terjadinya kelalaian staf medis dalam melakukan tindakan medis.

\section{Daftar Pustaka}

Achdiat, Chrisdiono M, Dinamika Etika dan Hukum Kedokteran dalam Tantangan Zaman, Jakarta: Buku Kedokteran EGC, 2007.

Ameln, Freed, Kapita Selekta Hukum Kedokteran, Jakarta: Grafikatama Jaya, 1991.

Bix, Brian, Jurisprudence: Theory and Context, London: Sweet \& Maxwell, 2012.

Bentham, Jeremy, Teori Perundang-undangan, Prinsip-prinsip Legislasi, Hukum Perdata dan Hukum Pidana, Bandung: Nuansa dan Nusa Media, 2010.

Barnett, Randy E, The Structure Of Liberty, Justice and The Rule Of Law, New York: Oxford University Press, 1998.

Cassese, Antonio, Hak Asasi Manusia Di Dunia Yang Berubah, Jakarta: Yayasan Obor Indonesia, 2005.

Christoffel, Tom, Health And The Law, The Free Press, New York, 1985.

Effendi, Mashuri., Hak Asasi Manusia Dalam Hukum Nasional dan Hukum Internasional, Jakarta: Ghalia Indonesia, 1994.

Fuady, Munir., Sumpah Hipocrates (Aspek Hukum Malpraktek Dokter), Bandung: Citra Aditya Bakti, 2005.

Garner, Bryan A, (Editor in Chief), Black Law Dictionary, Ninth Edition, West A Thomson Reuters Business, 2009.

Garrow, David. J., Liberty \& Sexuality, The Right to Privacy and The Making Of Roe and Wade, New York: MacMillan Publishing Company, 1994.

Campbell, EnidCs, Legal Research, Materials and Methods, Sydney: LBC Information Service, 1996.

Erwin, Muhamad, Filsafat Hukum 'Refleksi Kritis Terhadap Hukum', Cet. ke-3, Jakarta: Grafindo Persada, 2013.

Feibleman, James. K, Justice, Law and Culture, Martinus Nijhoff Publisher, , 1985. 
Fletcher, Goerge. P, Basic Concepts of criminal Law, Nedherland: Oxford University Press, 1998.

Francoeur, Robert T., Biomedical Ethics, A Guide to Decision Making, New York: A Wiley Medical Publication, 1983.

Golding, Martin P.and William A Edmundson (ed), The Blackwell Guide to The Philosophy of Law and Legal Theory, Australia: Blackwell Publishing, 2005.

Greene, Brendan, Essential Medical Law, London: Cavendish Publishing, 2001.

Garner, Bryan.A., Blacks Law Dictionary, Seven Edition, Minn: West Group, St Paul, 1999.

Hamdani, Nyowito, Ilmu Kedokteran Kehakiman, edisi II, Jakarta: Gramedia Pustaka Utama, 1992.

Hadjon, Philipus, Perlindungan Hukum Bagi Rakyat Indonesia, Surabaya: Peradaban, 2007. Hart, H.L.A., Konsep Hukum (The Concept Of Law), Penerjemah M. Khozim, Bandung: Nusa Media, 2011.

Hanafiah Jusuf dan Amir Amri, Etika Kedokteran dan Hukum Kesehatan, Jakarta: Penerbit Buku Kedokteran EGC, 2009.

Hiariej, Eddy O.S., Prinsip-Prinsip Hukum Pidana, Yogyakarta: Cahaya Atma Pustaka, 2014. Jacobalis, samsi, Pengantar tentang Perkembangan Ilmu Kedokteran, etika Medis, dan Bioetika, Jakarta: Sagung Seto, 2005.

Kassim, Putri Namie Jahn, Law and Ethics Relating to Medical Profession, Malaysia: International Law Book Services, 2007.

Koeswadji, Hermien Hadiati, Hukum dan Masalah Medik, Surabaya: Airlangga University Press, 1982

Koeswadji, Hermien Hadiati (ed), Soeharyo, Haryono Mintaroem dan Woerjaningsih, Kejahatan Terhadap Nyawa, Asas-Asas, Kasus dan Permasalahannya, Surabaya: Sinar Wijaya, 1984.

Leenen dan Lamintang, Pelayanan Kesehatan dan Hukum (Suatu Studi Tentang Hukum Kesehatan), Bandung: Bina Cipta, 1991

Marzuki, Peter Mahmud, Penelitian Hukum, Cet 6, Jakarta: Kencana Prenada Media Group, 2010.

Pengantar Ilmu Hukum, Cet 3, Jakarta: Kencana Prenada Media Group, 2009.

Muladi, Hak Asasi Manusia, Hakekat, konsep dan Implikasinya Dalam Perspektif hukum dan Masyarakat, Bandung: Refika Aditama, 2009. 
Hak Asasi Manusia, Politik dan Sistem Peradilan Pidana, Badan Penerbit Semarang: Universitas Diponegoro, 1997.

Mijn, Van Der, Issues Of Health Law, Tim Pengkajian Hukum Kesehatan Badan Pembinaan Hukum Nasional dan PERHUKI dan IDI, 1984.

Marmoir, Andrei, Interpretation and Legal Theory, Revised Second Edition, Oxford and Portland Oregon: Hart Publishing, 2005.

Murphy, Mark. C., Philosophy of Law The Fundamental, Australia: Blackwell Publishing, 2007.

Muhammad, Abdulkadir., Etika Profesi Hukum, Bandung: Citra Aditya Bakti, 1997.

Mertokusumo, SudikNo. , Mengenal Hukum Suatu Pengantar, Yogyakarta: Liberty, 2008.

Muchtar, Masrudi., Bidan dan Dinamika Hukum Kesehatan Reproduksi di Indonesia, Yogyakarta: Aswaja Presindo, 2015.

Marpaung, Leden, Unsur-Unsur Perbuatan Yang Dapat Dihukum, Jakarta: Sinar Grafika, 1991.

Moeljatno, Asas-Asas Hukum Pidana, Jakarta: Bina Aksara, 1983.

Soeparto, Pitono etall (Ed), Etik dan Hukum di Bidang Kesehatan, Surabaya: Airlangga University Press, 2006.

Saleh, Ruslan., Perbuatan Pidana dan Pertanggungjawaban Pidana, Jakarta: Aksara Baru, 1981.

Seran, Marcel dan Anna Maria Wahyu Setyowati, Dilema Etika dan Hukum Dalam Pelayanan Medis, Bandung: Mandar Maju, 2010.

Sandel, Michael J., Justice A Reader, New York: Oxford University Press, 2007.

Sasangka Hari, Adnan Sagita, Peraturan Perundang-undangan tentang Hak Asasi Manusia, Bandung: Mandar Maju.

Sidharta, B.Arief, Refleksi Tentang Hukum (Pengertian-Pengertian Dasar Dalam Teori Hukum), Bandung: Citra Aditya Bhakti, 2011.

Triwibowo, Cecep., Etika dan Hukum Kesehatan, Yogyakarta: Nuha Medika, 2014. 